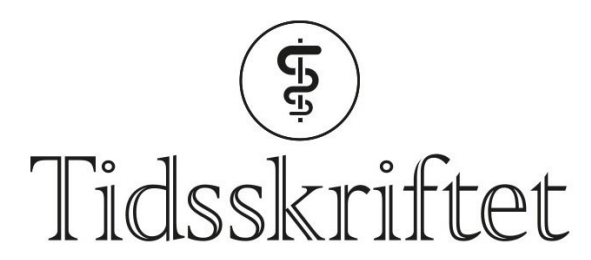

DEN NORSKE LEGEFORENING

\title{
Svekket tarmflora kan gi svekket immunisering
}

FRA ANDRE TIDSSKRIFTER

LISE SKOGSTAD LOFTSGAARD

Tidsskriftet

En ny studie viser at antibiotika svekker tarmfloraen og at dette kan gi dårligere immunrespons på influensavaksine.

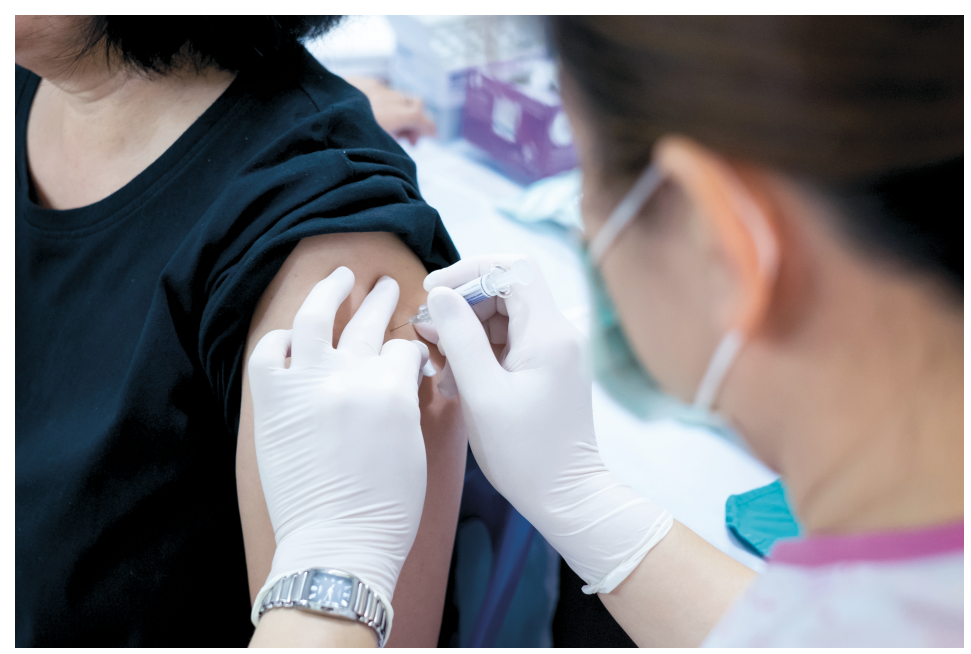

Illustrasjon: Byjeng/iStock

Tidsskriftet Cell har nylig publisert en studie av tarmfloraens rolle i immunitetsutvikling (1). Over to sesonger fulgte forskere immunresponsen til 22 friske mennesker som ble vaksinert med en trivalent vaksine mot sesonginfluensa. Deltakerne ble randomisert til å få en bredspektret antibiotikakur som ble påbegynt like før vaksinering, eller ingen slik behandling. Blant dem som fikk antibiotika fant man klar reduksjon i både mengde og artsmangfold av tarmbakterier, men immunresponsen var lik i de to gruppene.

For å avklare om dette kunne skyldes allerede opparbeidet immunitet, ble ytterligere 11 personer randomisert og behandlet på samme måte. Dette utvalget hadde lave antistofftitre før vaksinering og hadde ikke tatt influensavaksine de siste tre årene. Også denne gangen ble tarmfloraen negativt påvirket av antibiotikabehandling, men nå påviste man i tillegg en betydelig reduksjon i induksjonen av $\mathrm{A}\left(\mathrm{H}_{1} \mathrm{~N}_{1}\right)$-spesifikke antistoffer hos dem som hadde fått antibiotika ved flere måletidspunkter etter vaksinen.

- Dette er en spennende og viktig studie, sier Marius Trøseid, som er overlege og førsteamanuensis ved Seksjon for klinisk immunologi og infeksjonsmedisin, Oslo universitetssykehus. At utradering av intakt tarmflora gir redusert vaksinerespons, er 
interessant, men ikke helt uventet, sier han. - Vi vet blant annet at effekten av immunterapi med såkalte sjekkpunkthemmere er avhengig av intakt tarmflora for å gi optimal effekt.

- Et annet viktig funn i studien er at antibiotikabruk $\varnothing$ ker den inflammatoriske profilen i blodet, delvis gjennom aktivering av inflammasomet, sier Trøseid.

- Dette er kanskje ikke helt intuitivt og kan tyde på at immunapparatet prioriterer å regulere inflammasjonsresponsen fremfor å gi en adekvat immunrespons på vaksine.

\section{LITTERATUR:}

1. Hagan T, Cortese M, Rouphael N et al. Antibiotics-driven gut microbiome perturbation alters immunity to vaccines in humans. Cell 2019; 178:1313-1328.e13. [PubMed][CrossRef]

Publisert: 6. januar 2020. Tidsskr Nor Legeforen. DOI: 10.4045/tidsskr.19.0704

(C) Tidsskrift for Den norske legeforening 2020. Lastet ned fra tidsskriftet.no 